\title{
IDENTIFIKASI KEANEKARAGAMAN HAMA KUTU PUTIH (MEALYBUG) PADA TANAMAN SINGKONG DI KECAMATAN WONGSOREJO DAN KALIPURO
}

\author{
Hadi Hariyanto, N. Nurchayati, Agus Sufajari, Tristi Indah Dwi Kurnia \\ Program Studi Biologi, Fakultas Matematika dan Ilmu Pengetahuan Alam \\ Universitas PGRI Banyuwangi \\ Email: hadihariyanto18@gmail.com
}

\begin{abstract}
ABSTRAK
Kutuputih merupakan Hama yang dapat menurunkan produktifitas dari tanaman, salah satunya tanaman Singkong. Hama kutuputih biasanya bergerombol sampai puluhan ribu ekor. Mereka merusak dengan cara mengisap cairan. Semua bagian tanaman bisa diserangnya dari buah sampai pucuk. Serangan pada pucuk menyebabkan daun kerdil dan keriput seperti terbakar. Kabupaten Banyuwangi banyak lahan pertanian singkong yang terkena serangan hama kutu putih khususnya kecamatan Wongsorejo dan Kecamatan Kalipuro. Tujuan dilaksanakannya penelitian ini adalah Mengidentifikasi Keanekaragaman Hama Kutuputih (Mealybug) Pada Tanaman Singkong Di Kecamatan Wongsorejo Dan Kalipuro.Dalam penelitian ini ditemukan dua jenis kutu putih yang didapatkan melalui hasil pengamatan langsung di lapangan. Dua jenis kutu putih yang ditemukan di lokasi penelitian di Kecamatan Wongsorejo dan kecamatan Kalipuro yaitu dari Famili Pseudococcidae, genus Ferrisia spesies Ferisia virgata dan Genus Pharacocusspesies Pharacocus marginatus. Indeks Keanekaragaman hama kutu putih jenis $F$. virgata di Desa Wongsorejo $H^{\prime}=0,368$ kategori rendah, Indeks Keanekaragaman hama kutu putih jenis $F$. virgata di Desa Bangsring $H^{\prime}=0,267$ kategori rendah, dan Indeks Keanekaragaman hama kutu putih jenis $F$. virgata di desa bengkak $H^{\prime}=0,367$ kategori rendah. Sedangkan indeks keanekaragaman hama kutu putih jenis $P$. marginatus di Desa Wongsorejo $\mathrm{H}^{\prime}=0,286$ kategori rendah, indeks keanekaragaman hama kutuputih jenis $P$. marginatus di Desa Bangsring $\mathrm{H}^{\prime}=0,280$ kategori rendah dan indeks keanekaragaman hama kutuputih jenis $P$. marginatus di Desa Bengkak $H^{\prime}=0,280$ kategori rendah. Sedangkan, Indeks Keanekaragaman hama kutu putih jenis $F$. virgata di Desa Ketapang $\mathrm{H}^{\prime}=0,354$ kategori rendah, Indeks Keanekaragaman hama kutuputh jenis $F$. virgata di Desa Bulusan $H^{\prime}=0,362$ kategori rendah, dan Indeks Keanekaragaman hama kutuputih jenis $F$. virgata di desa Secang $H^{\prime}=0,366$ kategori rendah. sedangkan indeks keanekaragaman hama kutuputih jenis $P$. marginatus di Desa Ketapang $H^{\prime}=0,286$ kategori rendah, indeks keanekaragaman hama kutuputih jenis $P$. marginatus di Desa Bulusan $H^{\prime}=0,280$ kategori rendah dan indeks keanekaragaman hama kutuputih jenis $P$. marginatus di Desa Secang $\mathrm{H}^{\prime}=0,280$ kategori rendah.
\end{abstract}

Kata kunci : Singkong, Kutu Putih, dan Keanekaragaman.

\begin{abstract}
Melybug insects that can reduce the productivity of plants, one of which is the cassava plant. Mealybugs usually cluster up to tens of thousands of tails. They damage by sucking in liquids. it can attack all parts of the plant from fruit to shoots. Attacks on shoots cause stunted and wrinkled leaves as they burn. Banyuwangi Regency has a lot of cassava agricultural land that is affected by white flea pests, especially Wongsorejo and Kalipuro
\end{abstract}


districts. The purpose of this research was to identify the diversity of whitefly pests (Mealybug) on cassava plants in Wongsorejo and Kalipuro Districts.In this study, two types of mealybugs were found through direct observation in the field. Two types of mealybugs found at the research location in Wongsorejo District and Kalipuro District, namely from the Pseudococcidae family, the Ferrisia genus, the Ferisia virgata species and the Pharacocus genus, the Pharacocus marginatus species. Mealybug Diversity Index type $\mathrm{F}$. virgata in the village of Wongsorejo $\mathrm{H}^{\prime}=0.368$ low category, the diversity index of the mealybug type $\mathrm{F}$. virgata in Bangsring Village $\mathrm{H}^{\prime}=0.267$ low category, and the diversity index of the white flea pest of $F$. virgata in the village swelling $H^{\prime}=0.367$ low category. Meanwhile, the diversity index of the white bug type P. marginatus in the village of Wongsorejo $\mathrm{H}^{\prime}=0.286$ low category, the diversity index of the white bug species P. marginatus in Bangsring $\mathrm{H}$ village' $=0.280$ in the low category and the diversity index of the kutuputih pest type P. marginatus in Bengkak H Village ' $=0.280$ low category. Meanwhile, the Diversity Index of F. virgata in Ketapang Village, $\mathrm{H}$ '= 0.354 low category, the diversity index of the mealybug type $\mathrm{F}$. virgata in the village of Bulusan $\mathrm{H}^{\prime}=0.362$ low category, and the diversity index of the mealybug type F. virgata. in the village of Secang $H^{\prime}=0.366$ category low. while the diversity index of kutuputih type P. marginatus in Ketapang Village $\mathrm{H}^{\prime}=0.286$ category low, the diversity index of kutuputih type $\mathrm{P}$. marginatus in Bulusan $\mathrm{H}$ village' $=0.280$ low category and the diversity index of kutuputih pest species P. marginatus in Secang H Village ' $=0.280$ low category.

Keywords: Cassava, Melybug, and Diversity

\section{PENDAHULUAN}

Singkong (Manihot esculenta Crantz) berasal dari Benua Amerika, tepatnya dari Brazil dan merupakan tanaman pertanian yang penting di daerah tropis dan subtropis (Soetanto, 2008). Menurut Badan Pusat Statistik (BPS), tahun 2015, Indonesia menghasilkan lebih 24 juta ton singkong per tahun. Tahun 2016, diperkirakan produksi nasional sekitar 27 juta ton. Indonesia termasuk dari 3 (tiga) negara penghasil singkong terbesar di dunia setelah Nigeria dan Thailand. Di kabupaten Banyuwangi sendiri terhitung sejak tahun 2011-2016 produksi singkong rata-rata 35.124 ton pertahun, luas lahan pertanian singkong di daerah wongsorejo khususnya 850 ha dengan hasil produksi 16.200 ton, sedangkan luas pertanian singkong didaerah kalipuro 44 ha dengan hasil produksi 825 ton (Dinas Pertanian dan Kehutanan Kabupaten Banyuwangi, 2012).

Berdasarkan data Badan Pusat Statistik (2012) produksi singkong di Indonesia mengalami penurunan tercatat pada tahun 2011 produksi singkong mencapai 240 juta ton sedangkan pada tahun 2012 hanya 226 juta ton. Penurunan produktivitas mengindikasikan adanya kendala dalam budidaya singkong. Kendala tersebut 
dapat berasal dari aspek budidaya, iklim, maupun hama penyakit tanaman yang menyerang tanaman singkong.

Hama penyakit tanaman yang menyerang tanaman singkong salahsatunyaadalah Hama Kutuputih. Hama kutu putih menyerang tanaman singkong yang masih muda dan dapat menyebabkan kematian pada umur kurang dari tiga bulan sejak awal masa setelah tanam. Sehingga selama tiga bulan awal masa setelah tanam merupakan masa rawan terserang hama kutu putih. Serangan hama kutu putih menjadi ancaman besar bagi petani singkong di Indonesia pada tahun 2010 yaitu, kutu putih dari jenis Phenacoccus manihoti ditemukan menyerang pertanian singkong di Bogor (Muniappan et al., 2011). Kutu putih menyerang dengan cara menghisap cairan pada bagian daun dan pucuk tanaman. Gejala yang timbul akibat serangan tersebut, daun mengerut dan pucuk mengkerdil hingga menyerupai bunga atau disebut bunchy tops. Serangan kutu putih pada batang menyebabkan terjadinya distorsi yaitu kehilangan hasil produksi yang ditimbulkan dari serangan kutu putih berkisar 30-80\% (Dwi, 2017).

Persebaran Kutu putih pada tanaman singkong disebabkan oleh persebaran angin, kontak oleh tanaman lain, menempel pada tubuh manusia, dan ketinggian dataran tinggi 0-800 mdpl. Pada Hasil Penelitian (Nasution S, et al, 2012) menunjukan bahwa kutu putih lebih menyukai hidup pada ketinggian dibawah 200 mdpl. Hal ini disebabkan pada ketinggian tersebut suhu udara lebih tinggi sehingga sesuai untuk pertumbuhan dan perkembangbiakan kutu putih. Curah hujan dan angin juga berpengaruh pada kehidupan kutu putih, karena dengan ukuran tubuh yang kecil hama kutu putih bisa terjatuh, terbawa angin sehingga penyebaran hama kutuputih lebih cepat.

Saat ini informasi data sebaran hama kutu putih diwilayah Kabupaten Banyuwangi kecamatan wongsorejo dan kecamatan kalipuro khususnya masih dirasa minim informasi. Penelitian terakhir tentang kutu putih yang dilakukan di Banyuwangi dilakukan oleh Nurmasari, (2015). Berdasarkan penelitian tersebut, di Kabupaten Banyuwangi pada empat lokasi yaitu kelurahan Sobo, desa Secang, desa Kemiren, dan desa Glenmore ditemukan ada dua jenis spesies kutu putih 
yaitu: Paracocus marginatus dan Ferrisia virgata. Oleh karenanya, peneliti ingin mengangkat judul tentang "IDENTIFIKASI KEANEKARAGAMAN HAMA KUTU PUTIH Mealybug PADA TANAMAN SINGKONG DI KECAMATAN WONGSOREJO DAN KALIPURO" Penelitian tersebut diharapkan dapat menambah informasi tentang keanekaragaman hama kutu putih Mealybug pada tanaman singkong.

\section{METODE PENELITIAN}

\subsection{Waktu dan Tempat Penelitian}

Penelitian telah dilakukan selama 2 bulan yaitu bulan Mei sampai dengan bulan Juli 2018. Lokasi Penelitian dilakukan didua kecamatan, yaitu di Kecamatan Wongsorjo dan Kecamatan Kalipuro. Untuk Desa di Kecamatan Wongsorjo meliputi Desa Bengkak, Wongsorejo, Bangsring. Adapun untuk Kecamatan Kalipuro Meliputi Desa Ketapang, Secang, dan Bulusan. Untuk uji identifikasi spesies dilakukan di Laboratorium Biologi Universitas PGRI Banyuwangi.

\subsection{Alat dan Bahan}

Adapun alat yang digunakan antara lain: alat tulis, kamera digital, thermo higrometer, kertas label, cup kecil, corong, cutter, plastik gelap toples beserta tutupnya, pinset dan tali rafiah.Adapun bahan yang digunakan adalah daun tanaman singkong yang terserang hama kutu putih, Alkohol $70 \%$.

\subsection{Prosedur Penelitian}

Metode yang digunakan dalam penelitian ini adalah metode pengamatan langsung dan pengamatan sampel dengan prosedur sebagai berikut :

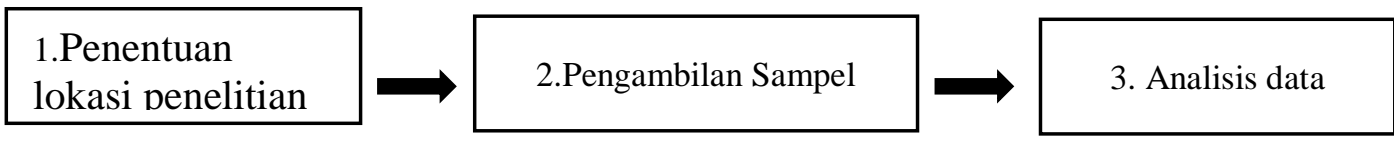

\subsubsection{Penentuan Lokasi penelitian}

Penelitian dilakukan didua kecamatan di kabupaten Banyuwangi yaitu Kecamatan Wongsorejo dan Kecamatan Kalipuro. Lokasi penelitian dipilih dengan melakukan survei pada kedua kecamatan tersebut.Survei dilakukan untuk 
memastikan bahwa pada lokasi sampling yang dituju terdapat populasi kutu putih. Setelah melakukan survei, maka dipilihlah 3 perwakilan desa untuk setiap satu kecamatan.

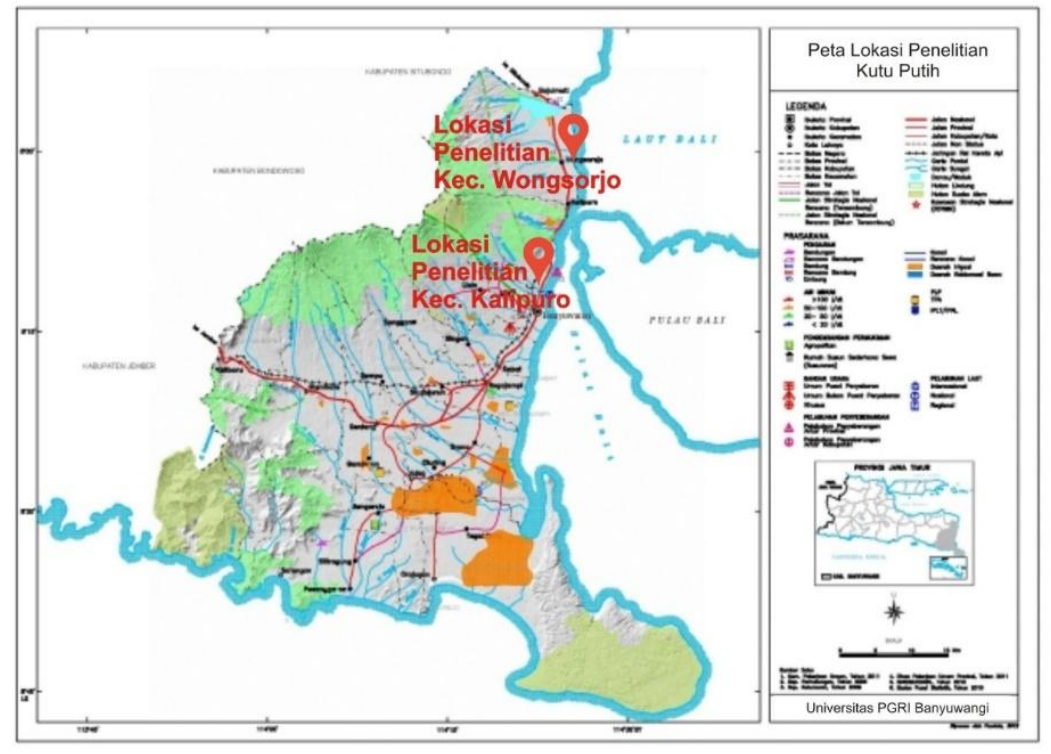

Gambar 3.1 peta Kabupaten Banyuwangi

Kriteria lokasi penelitian yang dapat digunakan dalam menentukan lokasi penelitian ini adalah lahan singkong yang memiliki ukuran lahan minimal $30 \mathrm{~m}^{2}$ atau minimal memiliki 30 tanaman singkong pada tiap lahannya dan merupakan lahan yang ditanami tanaman singkong berumur minimal 8 MST (Minggu Setelah Tanam). Lokasi yang dipilih di Kecamatan Wongsorejo adalah Desa Bengkak, Desa Wongsorejo, dan Desa Bangsring. Sedangkan lokasi yang dipilih pada Kecamatan Kalipuro meliputi Desa Ketapang, Desa Secang, dan Desa Bulusan.

\subsubsection{Pengambilan Sampel}

Pengambilan sampel kutu putih dilakukan dengan cara mengambil langsung hama kutu putih pada sampel daun singkong yang terinfeksi dikecamatan Wongsorejo dan Kalipuro. Pengambilan sampel menggunakan teknik random. Sampel diambil dari satu petak lahan masing-masing berukuran $30 \mathrm{M}^{2}$ dan ditentukan 5 titik dengan menggunakan pola diagonal seperti pada gambar 3.1 untuk menghindari pengambilan sampel ulang Pengambilan sampel penelitian dilakukan dengan mengumpulkan sampel daun tanaman singkong yang terinfeksi 
kutu putih di lima titik. Masing-masing titik diwakili oleh 3 helai daun yaitu 1 helai daun bagian atas, 1 helai daun bagian tengah, dan 1 helai daun bagian atas. Pengambilan sampel kutu putih dilakukan sebanyak 3 kali ulangan untuk setiap lokasi penelitian sehingga total ada 18 kali ulangan. Penelitian dilakukan dengan interval waktu 10 hari antar ulangan. Jumlah tanaman singkong yang diamati dalam satu kali ulangan adalah 10 tanaman singkong untuk tiap satu lahan singkong.

$17 \mathrm{~m}$

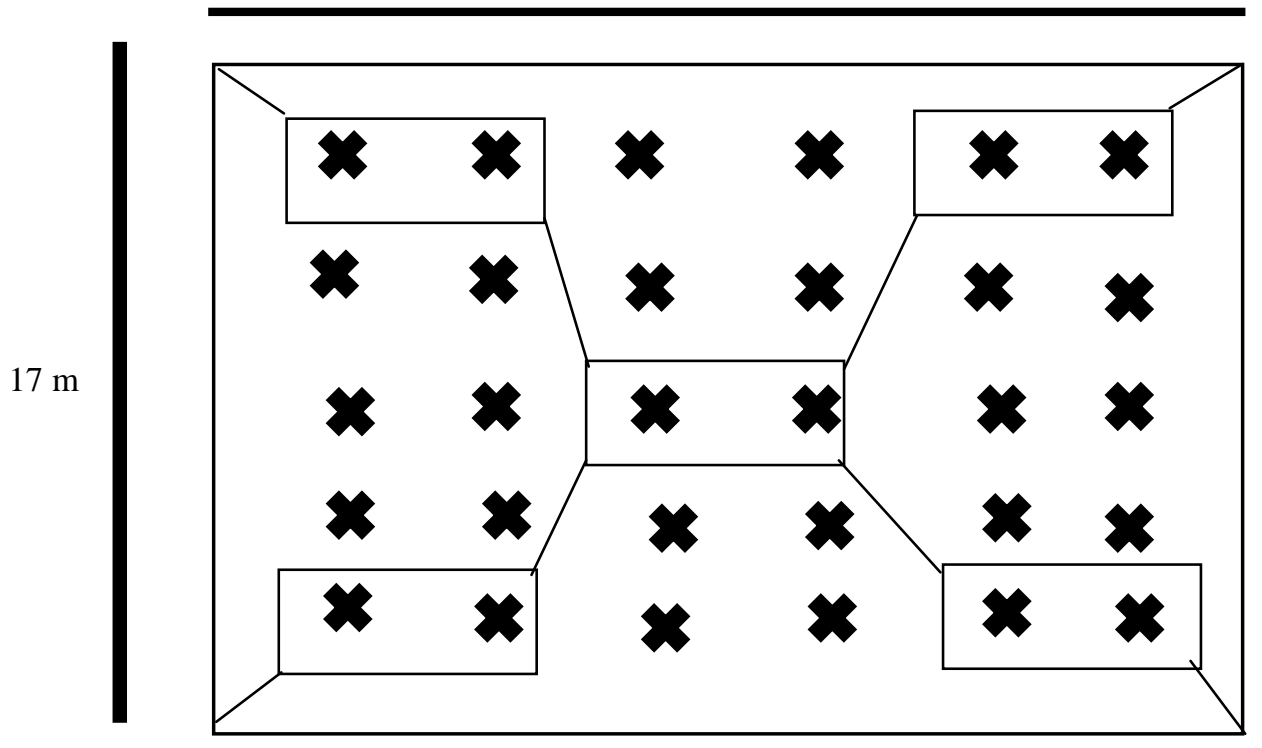

Gambar 3.2 Pola Pengambilan Sampel

Keterangan :

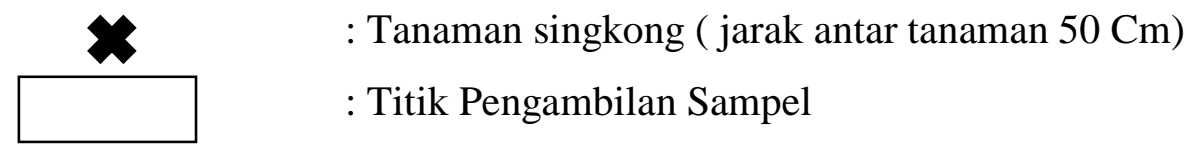

Pengambilan sampel kutu putih dilakukan pada pagi sampai menjelang siang hari yaitu pukul 09.00 sampai 11.30 wib dikarenakan pada pagi hari mobilitas kutu putih lebih tinggi untuk muncul pada permukaan daun dan memudahkan peneliti dalam mengidentifikasi dan menghitung jumlah kutu putih. Tahapan dalam pengambilan sampel kutu putih dilakukan dengan dua cara yaitu: Pertama, pengambilan kutu dengan metode mutlak yaitu pengamatan kutu putih secara langsung pada tanaman singkong sebanyak 3 kali ulangan untuk setiap satu lahan singkong. Setiap tanaman singkong dihitung seluruh jumlah kutu putih dengan 
memilih bagian tanaman yang terinvasi. Kedua, melakukan koleksi langsung kutu putih dengan mengambil langsung sampel kutu putih pada helaian daun tanaman singkong. Sampel daun yang diambil merupakan helaian daun yang memiliki jumlah kutu putih paling banyak pada tanaman singkong tersebut. Daun yang diamati adalah seluruh daun dari tanaman singkong, dari daun muda sampai daun tua. Daun yang terserang 1 nimfa dan imago sudah dianggap terserang oleh kutu putih. Pengamatan dilakukan dengan cara mengamati secara langsung pada setiap lokasi penelitian yang terkena serangan kutu putih, kemudian dihitung jumlah daun yang terserang hama kutu putih di setiap lokasi dan menghitung jumlah total daun yang terserang hama kutu putih di seluruh lahan singkong.

\subsection{Parameter Pengamatan}

\section{Keanekaragaman Spesies}

Indeks Shannon-Wiener (Magurran, 2004) digunakan untuk mengetahui keanekaragaman spesies pada setiap habitat, dengan rumus :

$$
\mathrm{H}^{\prime}=-\Sigma\left(\frac{n i}{N}\right) \ln \left(\frac{n i}{N}\right)
$$

Keterangan :

H' = Indeks Shannon Wiener

ni $=$ Jumlah individu untuk spesies yang diamati

$\mathrm{N}=$ Jumlah total individu

Indeks keanekaragaman dikelompokkan dalam tiga kriteria, yaitu : apabila $\mathrm{H}^{\prime}$ $<1$, maka keragaman rendah. Selanjutnya apabila $H^{\prime}=1<H^{\prime}<3$ maka keanekaragaman sedang dan apabila nilai $\mathrm{H}^{\prime}>3$ maka keanekaragamannya tinggi.

\section{Kelimpahan Jenis}

$$
K i=\frac{\text { jumlah individu jenis } A}{\text { jumlah unit contoh/luas }}
$$


Kelimpahan/kerapatan jenis adalah jumlah individu persatuan luas. Kelipahan dari masing-masing jenis pada setiap stasiun dihitung dengan menggunakan rumus yang telah dinyatakan sebagai berikut (Suin, 2012)

\section{HASIL DAN PEMBAHASAN}

Penelitian kutu putih pada tanaman singkong dilakukan di dua Kecamatan di Kabupaten Banyuwangi yaitu Kecamatan Wongsorejo meliputi Desa Wongsorejo, Desa Bangsring, Desa Bengkak dan Kecamatan Kalipuro meliputi Desa Ketapang, Desa Bulusan, dan Desa Secang. Hasil identifikasi morfologi kutu putih diperoleh data pada tabel 3.1

Tabel 3.1 Klasifikasi Kutu Putih (Mealibug)

\begin{tabular}{llll}
\hline NO & Famili & Genus & Spesis \\
\hline 1 & Pseudococcidae & Paracoccus & Paracoccus marginatus \\
\hline 2 & Pseudococcidae & Ferrisia & Ferrisia virgata \\
\hline
\end{tabular}

Berdasarkan Tabel 3.1 dalam penelitian ini ditemukan dua jenis kutu putih yang didapatkan melalui hasil pengamatan langsung di lapangan. Dua jenis kutu putih yang ditemukan di lokasi penelitian di Kecamatan Wongsorejo dan kecamatan Kalipuro yaitu dari Famili Pseudococcidae, genus Ferrisia spesies Ferisia virgata dan Genus Pharacocus spesies Pharacocus marginatus.

jenis kutuputih yang didapatkan di Kecamatan Wongsorejo yang diambil sampel tiga Desa meliputi Desa Wongsorejo, Desa Bangsring, dan Desa Bengkak didapatkan dua spesies kutu putih yaitu dari Famili Pseudococcidae, genus Ferrisia spesies Ferisia virgata dengan jumlah 895 individu/spesies di Desa Wongsorejo, 988 individu/spesies di Desa Bangsring, dan 885 individu/spesies di Desa Bengkak. Sedangkan pada Famili Pseudococcidae,Genus Pharacocus spesies Pharacocus marginatus didapatkan jumlah 1.592 individu/spesies di Desa Wongsorejo, 1.833 individu/spesies di Desa Bangsring dan 1.640 individu/spesies di Desa Bengkak. Adapaun individu terbanyak didapatkan dari spesies Pharacocus marginatus di ketiga Desa yang ditemukan dengan total 5.069 individu/spesies. Sedangkan spesies terendah didapatkan dari jenis Ferisia virgata dengan total 2.768 individu/spesies yang ditemukan di ketiga Desa di Kecamatan 
Wongsorejo.Untuk jumlah spesies kutu putih tertinggi yang ditemukan di ketiga Desa di Kecamatan Wongsorejo didapatkan di Desa Bangsring dengan total 2.825 individu, sedangkan jumlah spesies kutu putih terendah didapatkan di Desa Wongsorejo dengan jumlah kutu putih 2.487 individu.Data jumlah individu/spesies yang didapatkan di Kecamatan Wongsorejo disajikan dalam gambar diagram dibawah.

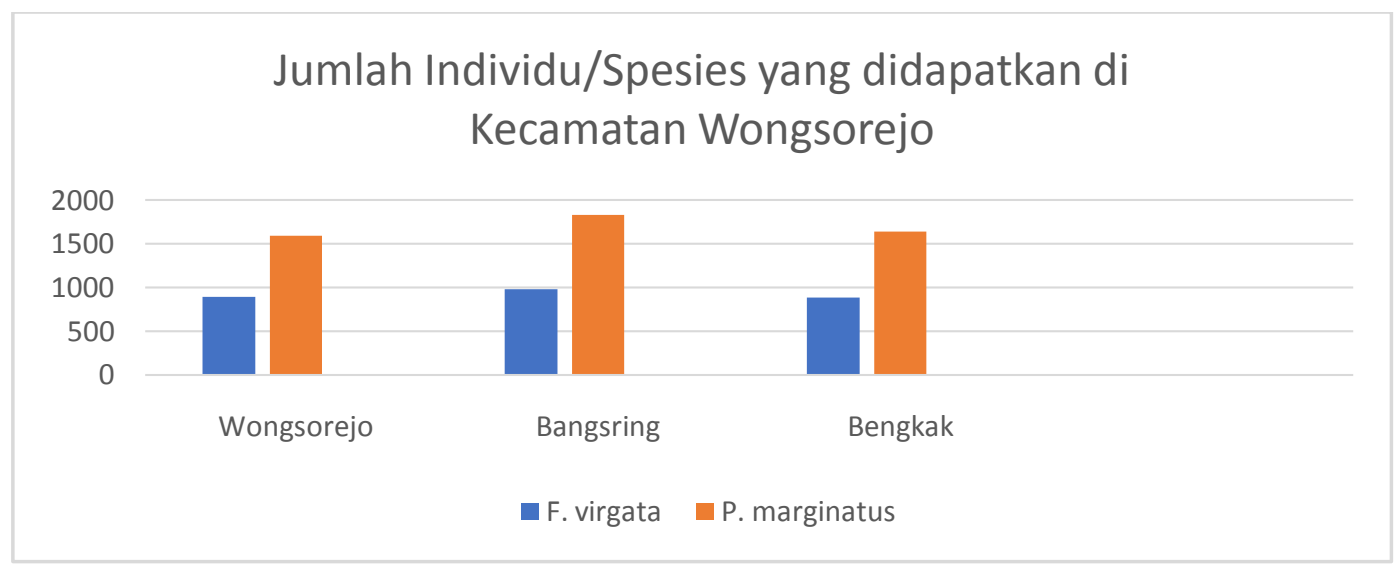

Gambar 3.1 Jumlah Individu/Spesies yang didapatkan di Kecamatan Wongsorejo

Sedangkan jenis kutuputih yang didapatkan di Kecamatan Kalipuro yang diambil sampel tiga Desa meliputi Desa Ketapang, Desa Bulusan, dan Desa Secang didapatkan dua spesies kutu putih yaitu dari Famili Pseudococcidae, genus Ferrisia spesies Ferisia virgata dengan jumlah 840 individu/spesies di Desa Ketapang, 972 individu/spesies di Desa Bulusan, dan 1.073 individu/spesies di Desa Secang. Sedangkan pada Famili Pseudococcidae, Genus Pharacocus spesies Pharacocus marginatus didapatkan jumlah 2.247 individu/spesies di Desa Ketapang, 2.208 individu/spesies di Desa Bulusan dan 2.146 individu/spesies di Desa Secang. Adapaun individu terbanyak didapatkan dari spesies Pharacocus marginatus di ketiga Desa yang ditemukan dengan total 6.601 individu/spesies. Sedangkan spesies terendah didapatkan dari jenis Ferisia virgata dengan total 2.885 individu/spesies yang ditemukan di ketiga Desa di Kecamatan Wongsorejo. Untuk jumlah spesies kutu putih tertinggi yang ditemukan di ketiga Desa di Kecamatan Wongsorejo didapatkan di Desa Bangsring dengan total 3.219 individu, sedangkan jumlah spesies kutu putih terendah didapatkan di Desa 
Wongsorejo dengan jumlah kutu putih 3.087 individu.Data jumlah individu/spesies yang didapatkan di Kecamatan Wongsorejo disajikan dalam gambar diagram dibawah.

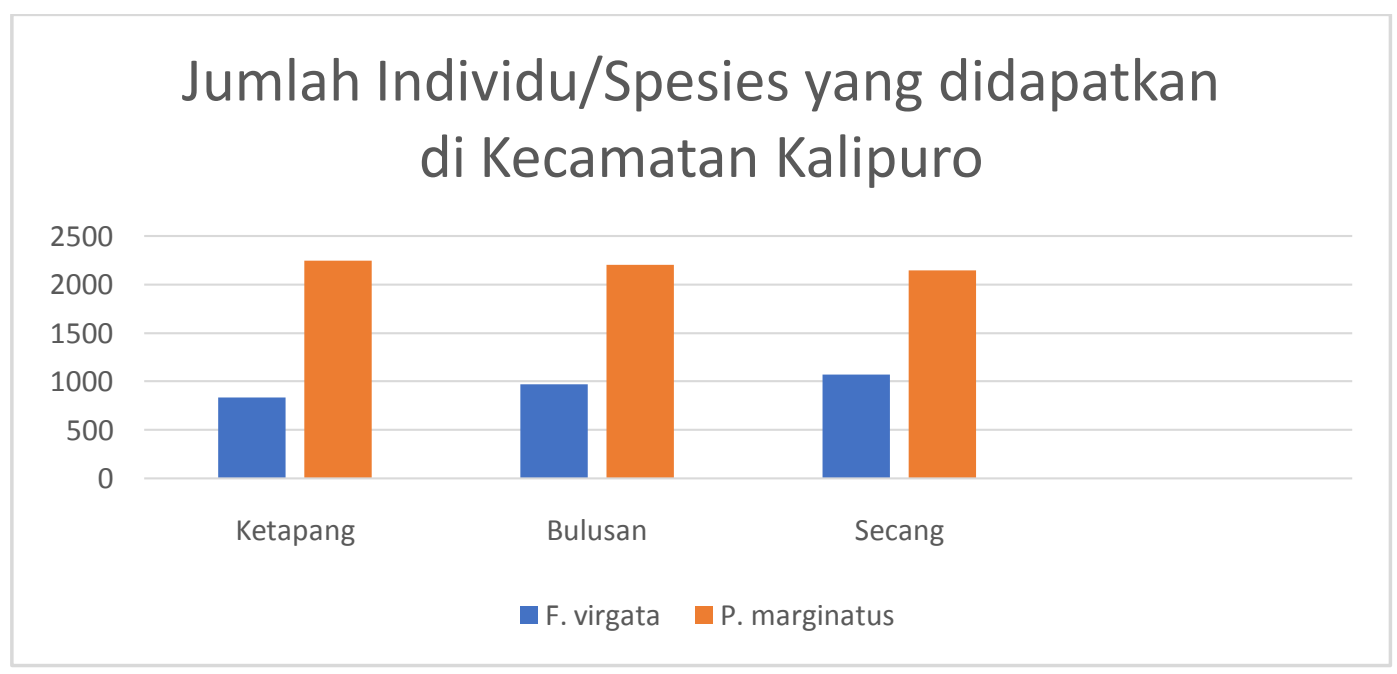

Gambar 3.1 Jumlah Individu/Spesies yang didapatkan di Kecamatan Wongsorejo

Keanekaragaman merupakan sebuah parameter biologi pada suatu komunitas yang kemudian dapat ditentukan kekayaan jenis keanekaragamannya. Menurut Widodo (1997), salah satu faktor yang mempengaruhi jumlah dan keanekaragaman jenis organisme adalah kondisi habitat organisme tersebut ketinggian dan juga faktor perubahan iklim atau cuaca. Indeks Keanekaragaman kutu putih tanaman singkong pada Enam lokasi penelitian meliputi Kecamatan Wongsorejo dan kecamatan Kalipuro hampir sama, tertinggi ditemukan di Desa Wongsorejo Kecamatan Wongsorejo $\mathrm{H}^{\prime}=0,653$ Kategori rendah, sedangkan indeks keanekaragaman terendah ditemukan di Desa Ketapang Kecamatan Kalipuro $\mathrm{H}^{\prime}=0,585$ kategori rendah. Brower (1990) menjelaskan bahwa nilai indeks keanekragaman dikatagorikan menjadi tiga, yaitu jika nilai $\mathrm{H}^{\prime}=<1$ maka nilai indeks keanekaragman dikatagorikan menjadi rendah. Jika nilai indek keanekaragaman menunjukkan nilai $1<\mathrm{H}^{\prime}<3$ maka dikatagorikan sebagai keanekaragaman sedang dan jika nilai indeks keanekaragaman menunjukkan nilai $\mathrm{H}^{\prime}=>3$, maka nilai indeks keaekaragaman dikatagorikan tinggi.

Tabel 3.2 Indeks Data Keanekragaman kutuputih di kecamatan Wongsorejo 


\begin{tabular}{lllll}
\multirow{2}{*}{ NO } & Spesies & $\mathrm{H}^{`}$ & & \\
& & Wongsorejo & H Bangsring & H Bengkak \\
\hline 1 & Ferisia virgata & 0,368 & 0,367 & 0,367 \\
\hline 2 & Pharacocus marginatus & 0,286 & 0,280 & 0,280 \\
\hline $\mathrm{N}$ & 0,653 & 0,647 & 0,648 \\
\hline Rata-rata & 0,649 & & \\
\hline
\end{tabular}

Berdasarkan data tabel 3.2 Indeks Keanekaragaman hama kutu putih jenis $F$. virgata di Desa Wongsorejo $\mathrm{H}^{\prime}=0,368$ kategori rendah, Indeks Keanekaragaman hama kutu putih jenis $F$. virgata di Desa Bangsring $H^{\prime}=0,267$ kategori rendah, dan Indeks Keanekaragaman hama kutu putih jenis $F$. virgata di desa bengkak $H^{\prime}=0,367$ kategori rendah. Sedangkan indeks keanekaragaman hama kutu putih jenis $P$. marginatus di Desa Wongsorejo $\mathrm{H}^{\prime}=0,286$ kategori rendah, indeks keanekaragaman hama kutuputih jenis $P$. marginatus di Desa Bangsring $\mathrm{H}^{\prime}=0,280$ kategori rendah dan indeks keanekaragaman hama kutuputih jenis $P$. marginatus di Desa Bengkak $H^{\prime}=0,280$ kategori rendah. Hasil nilai Rata-rata indeks keanekaragaman di Kecamatan Wongsorejo meliputi Desa Wongsorejo, Desa Bangsring dan Desa Bengkak $\mathrm{H}^{\prime}=0,649$ menunjukkan bahwa keanekaragaman spesies kutu putih di Wilayah Kecamatan Wongsorejo kategori rendah.

Tabel 3.3 Indeks Keanekragaman kutuputih di kecamatan Wongsorejo

\begin{tabular}{lllll}
\hline NO & Spesies & H` Ketapang & H` Bulusan & H`Secang \\
\hline 1 & Ferisia virgata & 0,354 & 0,362 & 0,366 \\
\hline 2 & Pharacocus marginatus & 0,231 & 0,253 & 0,270 \\
\hline $\mathrm{N}$ & & 0,585 & 0,616 & 0,637 \\
\hline Rata-rata & 0,612 & & \\
\hline
\end{tabular}

Berdasarkan data tabel 3.3 Indeks Keanekaragaman hama kutu putih jenis $F$. virgata di Desa Ketapang $\mathrm{H}^{\prime}=0,354$ kategori rendah, Indeks Keanekaragaman hama kutu putih jenis $F$. virgata di Desa Bulusan $H^{\prime}=0,362$ kategori rendah, dan Indeks Keanekaragaman hama kutu putih jenis $F$. virgata di desa Secang $H^{\prime}=0,366$ kategori rendah. sedangkan indeks keanekaragaman hama kutuputih jenis $P$. marginatus di Desa Ketapang $\mathrm{H}^{\prime}=0,286$ kategori rendah, indeks keanekaragaman hama kutuputih jenis P. marginatus di Desa Bulusan $\mathrm{H}^{\prime}=0,280$ 
kategori rendah dan indeks keanekaragaman hama kutuputih jenis $P$. marginatus di Desa Secang $H^{\prime}=0,280$ kategori rendah. Hasil nilai Rata-rata indeks keanekaragaman di Kecamatan Kalipuro meliputi Desa Ketapang, Desa Bulusan dan Desa Secang $H^{\prime}=0,612$ menunjukkan bahwa keanekaragaman spesies kutuputih di Wilayah Kecamatan Kalipuro kategori rendah.

Tabel 3.4 Kelimpahan jenis kutuputih di kecamatan Wongsorejo

\begin{tabular}{lllll}
\hline NO & Spesies & Wongsorejo & Bangsring & Bengkak \\
\hline 1 & Ferrisia virgata & 30 & 33 & 30 \\
\hline 2 & Paracoccus marginatus & 53 & 61 & 55 \\
\hline
\end{tabular}

Berdasarkan data tabel 4.6 Kelimpahan jenis (Density) hama kutu putih jenis Ferrisia virgata dalam satu petak ladang berukuran $30 \mathrm{~m}^{2}$ di Desa Wongsorejo 30 ekor $/ \mathrm{m}^{2}$, Desa Bangsring 33 ekor $/ \mathrm{m}^{2}$, Desa Bengkak 30 ekor $/ \mathrm{m}^{2}$, Sedangkan kelimpahan jenis (Density) hama kutu putih jenis $P$. marginatus dalam satu petak ladang berukuran $30 \mathrm{~m}^{2}$ di Desa Wongsorejo 53 ekor/m², Desa Bangsring 61 ekor/m², Desa Bengkak 55 ekor $/ \mathrm{m}^{2}$. Adapun kelimpahan kutu putih jenis $F$. virgata tertinggi didapatkan 33 ekor $/ \mathrm{m}^{2}$ di Desa Bangsring. Sedangkan kelimpahan kutu putih jenis $P$. marginatus tertinggi didapatkan $61 \mathrm{ekor} / \mathrm{m}^{2}$ di Desa Bangsring dan kelimpahan kutu putih jenis $P$. marginatus terendah didapatkan 53 ekor/m² di Desa Wongsorejo.

Tabel 3.5 Kelimpahan jenis Kutuputih di kecamatan Kalipuro

\begin{tabular}{lllll}
\hline NO & Spesies & Ketapang & Bulusan & Secang \\
\hline 1 & Ferrisia virgata & 28 & 32 & 36 \\
\hline 2 & Paracoccus marginatus & 75 & 74 & 72 \\
\hline
\end{tabular}

Berdasarkan data tabel 4.7 Kelimpahan jenis hama kutu putih jenis Ferrisia virgata dalam satu petak ladang berukuran $30 \mathrm{~m}^{2}$ di Desa Ketapang 28 ekor/ $\mathrm{m}^{2}$, Desa Bulusan 32 ekor $/ \mathrm{m}^{2}$, Desa Secang 36 ekor $/ \mathrm{m}^{2}$, sedangkan Kelimpahan jenis hama kutu putih jenis $P$. marginatus dalam satu petak ladang berukuran $30 \mathrm{~m}^{2} \mathrm{di}$ Desa Ketapang 75 ekor/ m², Desa Bulusan 74 ekor/m², Desa Secang 72 ekor/ m². Adapun kelimpahan kutu putih jenis $F$. virgata tertinggi didapatkan $36 \mathrm{ekor} / \mathrm{m}^{2} \mathrm{di}$ Desa Secang dan kelimpahan kutu putih jenis $F$. virgata terendah didapatkan. \begin{tabular}{l}
\hline Identifikasi Keanekaragaman Hama Kutu Putih (Mealybug) Pada Tanaman Singkong Di Kecamatan Wongsorejo Dan 12 \\
Kalipuro
\end{tabular} 
sedangkan kelimpahan kutu putih jenis $P$. marginatus tertinggi didapatkan 75 ekor/m² di Desa Ketapang dan kelimpahan kutu putih jenis P. marginatus terendah didapatkan 72 ekor/m² di Desa Secang.

\section{KESIMPULAN DAN SARAN}

\subsection{Kesimpulan}

Dalam penelitian ini ditemukan dua jenis kutu putih yang didapatkan melalui hasil pengamatan langsung di lapangan. Dua jenis kutu putih yang ditemukan di lokasi penelitian di Kecamatan Wongsorejo dan kecamatan Kalipuro yaitu dari Famili Pseudococcidae, genus Ferrisia spesies Ferisia virgata dan Genus Pharacocus spesies Pharacocus marginatus. Indeks Keanekaragaman kutu putih tanaman singkong pada Enam lokasi penelitian meliputi Kecamatan Wongsorejo dan kecamatan Kalipuro hampir sama, tertinggi ditemukan di Desa Wongsorejo Kecamatan Wongsorejo $\mathrm{H}^{\prime}=0,653$ Kategori rendah, sedangkan indeks keanekaragaman terendah ditemukan di Desa Ketapang Kecamatan Kalipuro H'= 0,585 kategori rendah.

Kelimpahan jenis (Density) hama kutu putih jenis Ferrisia virgata dalam satu petak ladang berukuran $30 \mathrm{~m}^{2}$ di Desa Bengkak Kecamatan Wongsorejo 29 ekor/m², Desa Wongsorejo Kecamatan Wongsorejo 30 ekor $/ \mathrm{m}^{2}$, Desa Bangsring Kecamatan Wongsorejo 33 ekor/m², Desa Ketapang Kecamatan Kalipuro 28 ekor/m², Desa Bulusan Kecamatan Kalipuro 32 ekor $/ \mathrm{m}^{2}$, Desa Secang, Kecamatan Kalipuro 36 ekor/m². Sedangkan kelimpahan jenis (Density) hama kutu putih jenis P. marginatus dalam satu petak ladang berukuran $30 \mathrm{~m}^{2}$ di Desa Bengkak Kecamatan Wongsorejo 15 ekor/m², Desa Wongsorejo Kecamatan Wongsorejo 15 ekor/m², Desa Bangsring Kecamatan Wongsorejo 14 ekor $/ \mathrm{m}^{2}$, Desa Ketapang Kecamatan Kalipuro 16 ekor/m², Desa Bulusan Kecamatan Kalipuro 18 ekor/m², Desa Secang, Kecamatan Kalipuro 19 ekor $/ \mathrm{m}^{2}$.

\subsection{Saran}

1. Perlu adanya pengembangan penelitian terhadap keanekaragaman Hama pada tanaman singkong.

2. Perlu adanya kajian lebih lanjut tentang musuh alami hama kutu putih pada tanaman singkong. 


\section{REFERENSI}

Amarasekare KG, Mannion KM, Osborne LS, Epsky ND. 2008. Life history of Paracoccus marginatus (Hemiptera: Pseudococcidae) on four host plant species under laboratory conditions. Environ Entomol. 37:630-635.

Bellotti AC. 2002. Arthropod pests. Di dalam: Hillocks RJ, editor. Cassava: Biology, Production and Utilization. Wallingford (GB): CAB InternasionalPublishing. hlm 209-235.

Bellotti AC, Melo EL, Arias B, Herrera CJ, Hernandez MDP, Holguin CM, Guerrero JM, Trujillo H. 2003. Biological control in the neotropics: a selective review with emphasis on cassava. Biologic Contr Arthrop. Hlm 206-277.

Birch LC. 1948. The intrinsic rate of natural increase of an insect population. $J$ Anim Ecol. 17:15-26.[BPS] Badan Pusat Statistik. 2012. Luas panen, produktivitas, produksi tanamanubikayu seluruh provinsi. Jakarta (ID): Badan Pusat Statistik. [internet].[diunduh 2014 Nov 3]. Tersedia pada:www.bps.go.id/tnmn_pgn.php?kat=3.

Calatayud PA, Le Rü B. 2006. Cassava Mealybug Interactions. Paris (FR): Institut De Recherche Pour Le Développement.

Chandra D. 2008." Inventarisasi hama dan penyakit pada pertanaman Jarak pagar (Jathropa curcas Linn) di Lampung dan Jawa Barat". Tidak Diterbitkan. Skripsi. Program Studi Hama dan Penyakit Tumbuhan, Fakultas Pertanian, Institut Pertanian Bogor.

Ditjentan. 2012. Pedoman Teknis Pengelolaan Produksi Ubikayu. Jakarta (ID): Direktorat Jenderal Tanaman Pangan, Kementrian Pertanian.

Flint LM, Dreistadt HS. 1998. Natural Enemies Handbook, The Illustrated Guide to Biological Pest Control. UC Division of Agriculture and Natural Resources. University of California Press

Hafsah MJ. 2003. Bisnis Ubi Kayu Indonesia. Jakarta (ID): Pustaka Sinar Harapan.

Herren H. 1981. IITA's role and actions in controlling the cassava mealybug in Africa. IITA Research Briefs. 2(4):1-4.

Herren HR, Neuenschwander P. 1991. Biological control of cassava pests in Africa. Annu Rev Entomol. 36:257-283.

Iheagwam EU. 1981. The influence of temperature on increase rates of the cassava mealybug Phenacoccus manihoti Mat-Ferr (Homoptera: Pseudococcidae). Rev Zool Afr. 95(4):959-967.

Iheagwam EU, Eluwa MC. 1983. The effects of temperature on the development of the immature stages of the cassava mealybug, Phenacoccus manihoti

Krebs, C.J. 1989 . Ecology, the Experimental analysisof distributions and abundance. Harper and Row Publication.Inc. New York

Lema KM, Herren HR. 1985. The influence of constant temperature on populatin growth rates of the cassava mealybug, Phenacoccus manihoti. Entomol ExpAppl. 38(2):165-169.

Maia AHN, Luiz AJB, Campanhola C. 2000. Statistical infence on associated fertility life table parameter using jackknife technique: computational aspects. $J$ Econ Entomol. 93(2):511-518. 
Muniappan R, Shepard BM, Watson GW, Carner GR, Rauf A, Sartiami D, Hidayat P, Afun JVK, Goergen G, Rahman AKMZ. 2011. New records of invasive insects (Hemiptera: Sternorrhyncha) in southern Asia and West Africa. J Agric Urban Entomol. 26(4):167-174.

Neuenschwander P. 2001. Biological control of the cassava mealybug in Africa: a review. Biol Control. 21:214-229.

Nwanze KF, Leuschner K, Ezaumah HC. 1979. The cassava mealybug, Phenacoccus sp. in the Republic of Zaire. PANS. 25(2):125-130.

Pramayudi N, Oktarina H. 2012. Biologi Hama Kutu Putih Pepaya (Paracoccus marginatus) pada tanaman pepaya. J. Floratek 7: $32-44$

Purnomo H. 2010. Pengantar Pengendalian Hayati. Yogyakarta. Andi

Parsa S, Kondo T, Winotai A. 2012. The cassava mealybug (Phenacoccus manihoti) in Asia: first records, potential distribution, and ad identificationkey. PLOS ONE [Internet]. 7(10):e47675. DOI:10.1371/journal.pone.0047675.

Rauf, A. 2008 . Hama kutu putih Paracoccus marginatus. Pusat Penelitian Ilmu Hama Tanaman. Institut Pertanian Bogor.

Schulthess F, Baumgartner JU, Herren HR. 1987. Factors influencing the life table statistics of the cassava mealybug Phenacoccus manihoti. Int $J$ TropInsect Sci. 8(4-6):851-856.

Tanwar RK, Jeyakumar P, and Vennila S. 2010. Papaya Mealybug and its Management Strategies. National Centre for Integrated Pest Management. New Delhi

Walker, A., M. Hoy and Meyerdirk. 2003 . Papaya mealybug (Paracoccus marginatus Williams and Granara de Willink (Insecta : Hemiptera; Pseudococcidae)). EENY - 302. Featured creatures. Entomology and Nematology Department, Florida Cooperative Extension Service, Institute of Food and Agricultural Sciences, University of Florida. Gainesville, FL. Available from http://if-srvv-edis.ifas.ufl.edu/pdffiles/in/in57900.pdf. diakses tanggal 5 April 2014

Williams DJ, Granara de Willink MC.1992. Mealybugs of Central and South America. Wallingford (GB): CAB International.

Zakaria.F. 2014. Kutu Putih Phenacoccus manihoti, hama "impor" baru pada tanaman ubi kayu. http://tanamanpangan.pertanian.go.id/ditlintp/berita-160kutu-putih-phenacoccus-manihoti-hama-\%E2\%80\%9Cimpor\%E2\%80\%9Dbaru-pada-tanaman-ubi-kayu.html Diakses pada tanggal 26 Januari 2014 